\title{
Antecedents to Consumer Ethnocentrism: A Fuzzy Logic-Based Analysis Study
}

\author{
Saeb Farhan Al Ganideh ${ }^{1}$, Ghaleb El Refae ${ }^{2}$ and Maher Al Omari ${ }^{3}$ \\ ${ }^{1}$ Al Zaytoonah University of Jordan, Amman, Jordan \\ ${ }^{2}$ AlAin University of Science and Technology, U.A.E \\ ${ }^{3}$ Yarmouk University, Irbid, Jordan
}

\begin{abstract}
This study empirically examines a segment of consumers within the Jordanian society who express high ethnocentric tendencies towards domestic products using fuzzy logic technique. MATLAB® ANFIS has been employed to model the relationships between three inputs (conservatism, dogmatism and world-mindedness) and one output (consumer ethnocentrism). The results of this research conclude that Sugeno type fuzzy model has the ability to predict precisely consumers ethnocentric tendencies levels based on their socio-psychological variables. Overall, fuzzy logic can improve the research of consumer ethnocentrism and can illuminate uncovered sides in the area of consumer ethnocentrism.
\end{abstract}

Keywords: Consumer ethnocentrism, Fuzzy logic, Socio- psychological variables

\section{Introduction}

\section{Literature Review}

The globalization of markets has changed the competitive conditions facing organizations (Wiersema and Bowen, 2008).Over the past two decades international investment activities have increased extraordinarily (Weng, et al 2010). Recently, global marketing activities have increased astonishingly due to the technical and communication developments (Chung et al 2009). Consumers' bias towards their national products is a significant determinant of local product purchase behavior (Josiassen, 2011). Indeed, exploring consumers' attitudes towards domestic and foreign products can help local and global marketers to conduct more effective local and global marketing strategies (Chéron and
Hayashi, 2001). Despite the sharp increase in foreign made products availability all around the world, little research focused on this interesting development (Lim and Darley, 2009).The increased consumer awareness of foreign cultures, global markets and foreign brands has increased the importance of studies that explore consumer ethnocentric tendencies (Nijssen and Herk, 2009). In this context, the concept of consumer ethnocentrism can help marketers to conduct effective marketing strategies. Organisations and companies, in fact, need to consider the level of consumer ethnocentrism among consumers before launching their products in foreign countries (Phau and Chan, 2003).Ethnocentrism is a purely sociological concept that distinguishes between in-groups and out-groups (Simp, 1984). It refers to blind acceptance to the in-group and blind rejection to out groups. It leads individuals to

Copyright (C) 2012 Saeb Farhan Al Ganideh, Ghaleb El Refae and Maher Al Omari. This is an open access article distributed under the Creative Commons Attribution License unported 3.0, which permits unrestricted use, distribution, and reproduction in any medium, provided that original work is properly cited. Contact author: Saeb Farhan Al Ganideh E-mail: saebfarhan@yahoo.co.uk 
overstate everything in their own culture that differentiates them from others (Al Ganideh, 2010). Therefore, ethnocentrism may cause contempt to other people and their cultures. It is clear that most individuals view their own group as the centre of the universe and evaluate other cultural groups from their perspective (Yu and Albaum, 2002).The earliest leading research on consumer ethnocentrism was conducted by Shimp and Sharma in 1987. The researchers define consumer ethnocentrism as: 'The beliefs held by the consumers about the appropriateness, indeed morality, of purchasing foreign made products' (p.240). Shimp and Sharma applied ethnocentrism to the study of marketing and consumer behaviour. They relate the term 'consumer ethnocentric tendencies' to consumers' beliefs related to the appropriateness and morality of purchasing foreign made products (Klein et al (1998). The concept of consumer ethnocentrism was developed to capture consumer emotions related to purchasing foreign made products (Shimp, 1984). Bruning (1997) argues that national loyalty and consumer ethnocentrism effects are the outcomes of group behaviour and initiate from group communication. According to Shimp and Sharma (1987), consumer ethnocentrism gives the individuals a sense of identity; feelings of belonging to the in-group.

Ethnocentric tendencies in consumers are a part of a constellation of social, psychological and demographic influences (Sharma et al 1995). Thus, it offers individuals a sense of distinctiveness, feelings of belongingness and a justification of why some purchase behaviours are suitable, or unsuitable to the group (Witkowski and Beach, 1998). Nevertheless, it is critical to recognize that consumer ethnocentrism tendencies may change due to time, historical events, economic crises or political status (Yu and Albaum, 2002). Generally, consumers become more ethnocentric towards purchasing local products during crisis time (Al Ganideh, 2010).
The consequences of consumer ethnocentrism (whether or not ethnocentrism leads consumers to purchase their national products) have been well researched (i.e Sharma et al 1995; Klein et al 1998; Kim and Pysarchik, 2000; Huddleston et al 2001; Orth and Firbasova, 2003). However, the sources of consumer ethnocentrism phenomenon have not been well acknowledged (Al Ganideh, 2010). It is crucial to be aware of what lead consumers to be ethnocentric. This study raises awareness of the importance of examining socio- psychological antecedents to consumer ethnocentrism in different countries and cultures. Earlier, Shimp and Sharma (1987) developed a scale to measure consumers' ethnocentric tendencies (CETSCALE) for purchasing foreign-versus American made products. Shimp and Sharma (1987) described their scale as a measure of tendency rather than attitudes, since attitude proposes a superior degree of objectivity specifically than the CETSCALE is intended to capture. The development and international application of the CETSCALE is a vital contribution to consumer research. The CETSCALE is the most widely used instrument to examine consumer ethnocentric tendencies (Klein et al 1998). It became a part of any company's tracking studies of consumer attitudes in domestic and foreign markets (Al Ganideh et al 2007). International companies and organizations could use the CETSCALE as part of their periodic tracking studies (Shimp and Sharma, 1987). However, marketers might find the CETSCALE less relevant and useful than giving more focused and precise information that provide specific insight concerning consumer aversion towards a particular country (Klein et al 1998).

\section{Consumer Ethnocentrism and Socio- psychological Antecedents}

Overall, there is a dearth of studies examining socio-psychological variables as antecedents to consumer ethnocentrism. Moreover, the results of previous empirical 
studies regarding the influences of sociopsychological antecedents on consumer ethnocentrism are inconsistent. Recently, a number of researchers have concentrated on exploring patriotism, nationalism and internationalism as antecedents of consumer ethnocentrism (i.eBalabaniset al 2001; Lee et al 2003; Al Ganidehet al 2007). The current study examines the influence of sociopsychological antecedents; namely, dogmatism, conservatism and worldmindedness on consumer ethnocentrism. Caruana and Magri (1996) define dogmatism as a personal attribute that differentiate reality in black and white. Caruana and Magri (1996) found in Malta that consumers with higher levels of dogmatism express higher levels of consumer ethnocentrism. Dogmatic individuals are those who hold beliefs and disbeliefs that are rigidly demarcated within the cognitive system (Crowson, 2009, p.265). Sharma et al (1995, p.28) define conservatism as 'a tendency to cherish traditions and social institution that have survived the test time and to introduce changes only occasionally, reluctantly and gradually'. Conservatism has become connected in the U.S. to the political opinions that defend liberty, good character, strong families and the importance of religion (Blitz, 2010, p.61). Overall, a devotion to the precedent is the core of conservatism (Strauss, 2011).

A positive relationship was found between conservatism and consumer ethnocentrism in South Korea (Sharma et al 1995). Ruyter et al (1998) found a positive significant influence for conservatism on consumer ethnocentrism for consumers from the Netherlands and Korea. Moreover, in France, Javalgiet al (2005) concluded that conservatism has a significant influence on consumer ethnocentrism. Rawwas and Rajendar (1996) argue that it is essential for international marketers to give attention to consumers' ideologies such as worldmindedness. World-mindedness does not mean cultural openness. A world-minded person is one whose most important reference group is mankind, rather than
Americans or English or Chinese (Nijssen and Douglas, 2008). It is a state of mind that uses humankind as reference group (Shankarmahesh, 2006). Rawwas and Rajendar (1996) indicated that worldminded consumers perceive higher quality for foreign products. Consumers should not interact with peoples from other cultures to be world-minded. Nevertheless, they just have to have positive attitudes towards problems of the humanity. Balabanis et al (2001) found that world-mindedness has no significant influence on consumer ethnocentrism for two samples from Turkey and the Czech Republic. However, Lee et al (2003) concluded that world-mindedness has negative significant influence on consumer ethnocentrism in the U.S.A. Surprisingly, Al Ganideh et al (2007) found that world-mindedness has positive significant influence on consumer ethnocentrism for a student sample in Jordan. Overall, the advantages of examining socio- psychological antecedents such as dogmatism, conservatism and worldmindedness to consumer ethnocentrism lie in the opportunities of segmenting consumers based on their favorable and unfavorable disposition to foreign products and could help to know more regarding the sources of consumer ethnocentrism phenomenon (Caruana and Magri 1996; Ruyter et al 1998; Shankarmahesh, 2006; Al Ganideh et al 2007). It is known that differences between consumers in different countries still exist due to diversities in culture. The concept of consumer ethnocentrism can help marketers to differentiate markets and strategies and to position their products very well domestically and globally. Overall, it is dangerous for domestic and global marketers to suppose that consumers all around the world are similar. Nevertheless, they need to know more about consumers and their attitudes all around the world. Yet, this research is the first that offers those interested in the area of consumer ethnocentrism all around the world more information and understanding about consumer ethnocentrism concept in Jordan. 
This research aims to examine sociopsychological variables; namely, dogmatism, conservatism and world mindedness as antecedents to consumer ethnocentrism for Jordanian consumers.

\section{Methodology}

Generally, fuzzy logic can improve the study in the area of customer preferences. The application of fuzzy logic theory to consumer behavior research can improve the research in the area of consumer ethnocentrism (Liu, 2009). Enache (2010) argues that fuzzy logic has started to help marketers and managers to probe new insights in their data. In this context, Al Ganideh et al (2011) indicated that fuzzy logic can help in developing the research of consumer ethnocentrism by giving accurate insights to international marketers regarding every single customer ethnocentric tendencies. To examine the influence of socio- psychological variables; namely, dogmatism, conservatism and worldmindedness on consumer ethnocentrism, a survey was conducted focusing on the Jordanian consumers. Jordanian consumers have a different culture and lifestyle to their American and European counterparts who have been mainly examined in earlier research (i.e Caruana and Magri, 1996; Kim and Pysarchik, 2000; Javalgi et al 2005). The respondents were asked to answer a modified 17-item 5-point Likert format CETSCALE (Shimp and Sharma, 1987)Jordanian modified version. Moreover, they were asked to answer 7-item 5-point Likert format Rawwas and Rejendran (1996) world-mindedness scale and 5-item 5-point Likert format Bruning et al (1985) dogmatism scale. These two scales were used in marketing studies. To measure conservatism, and due to the specialty of the Jordanian society, the respondents were asked to answer 4 item 5-point Likert format related to tribes in Jordan, tribal law, honor killing and the role of women in the political life in Jordan developed by the researchers based on open questions. The Cronbach's alpha measure of internal consistency was carried out to assess the overall reliability of the used scales. All used scales have been found very reliable as Cronbach's Alpha values have exceeded 0.70 for the four scales. The recommended minimum acceptable level of reliability for Cronbach's alpha is 0.60 , using Hair et al (1998). Out of 352 questionnaires distributed to random Jordanian shoppers in 3 main market areas in Irbid City (north of Jordan); Amman City (Centre of Jordan) and Karak City (south of Jordan), 272 were usable. Questionnaires with substantial missing data were excluded (Sekaran and Bougie, 2010). Data has been collected in October and November 2009. Pecher and Tregear (2000) criticized previous country-of-origin studies as many of them used students as samples and preferred to reach a broad profile of respondents by collecting data from major sites in city centers such as busy shopping streets.

\section{Analysis and Discussion}

Unquestionably, fuzzy logic can improve the research of consumer ethnocentrism and can illuminate uncovered sides in the area of consumer ethnocentrism. Fuzzy logic has been adopted to analyze the data in this study. The study is the first to apply fuzzy logic on a consumer ethnocentrism research. However, previous studies in the field of consumer ethnocentrism used traditional statistical techniques to examine the nature of relationships between socio- psychological variables and consumer ethnocentrism. Fuzzy logic has been used in large numbers of applications since it was first proposed by Zadeh in 1965. It is important to bear in mind that Zadeh has introduced a new methodology in defining notations that cannot be defined precisely. In a classical $\{0$, 1 ) set, an object can be either a member of the set or not a member of the set. However, in fuzzy sets defined by Zadeh (1965) objects can belong to the set with different degrees of membership. That means any number in the interval $[0,1]$ where 0 denotes that the object does not belong to the set at all, and 1 denotes that the object belongs completely to that group. Overall, there are four main 
components of a fuzzy system; namely, fuzzification module, inference engine, knowledge base and defuzzification). Fuzzification module converts a crisp input to its corresponding fuzzy value. In addition, inference engine (rule-based system) applies fuzzy rules to compute the output contributed by each rule individually. Moreover, knowledge base contains all the rules and membership functions. Furthermore, defuzzification module combines the several rules outputs into one crisp value and then denormalizes the output value if needed.

MATLAB® ANFIS, a training mechanism for Sugeno-type fuzzy inference system, has been used in the current study to model the relationship between three inputs dogmatism, conservatism and worldmindedness and one output ethnocentrism (Figure 1). Subtractive clustering was used to generate the fuzzy inference system where the clustering parameters were chosen as the following range of influence (0.5), squash factor (1.25), accept ratio (0.5) and reject ratio (0.15). Depending on the values of these three parameters, an 11 rules fuzzy inference system (FIS) was generated with 9 membership functions for each variable of inputs and the output.

The following are the specifications of the used fuzzy inference system: type: 'sugeno' and Method: 'prod' or Method: 'probor' defuzz Method: 'wtaver' imp Method: 'prod' agg Method: 'max' input: [1x3 struct]output: [1x1 struct] rule: [1x9 struct] trndata: [272x4 double]. A first order Sugeno type fuzzy model has three inputs ( $\mathrm{x}, \mathrm{y}$, and $\mathrm{z}$ ) and one output (f) and it has rules of the following form:

IF $x$ is $a_{1}$ and $y$ is $b_{1}$ and $z$ is $c_{1}$ Then $f$ is $h_{1} x+i_{1} y$ $+j_{1} Z+r$

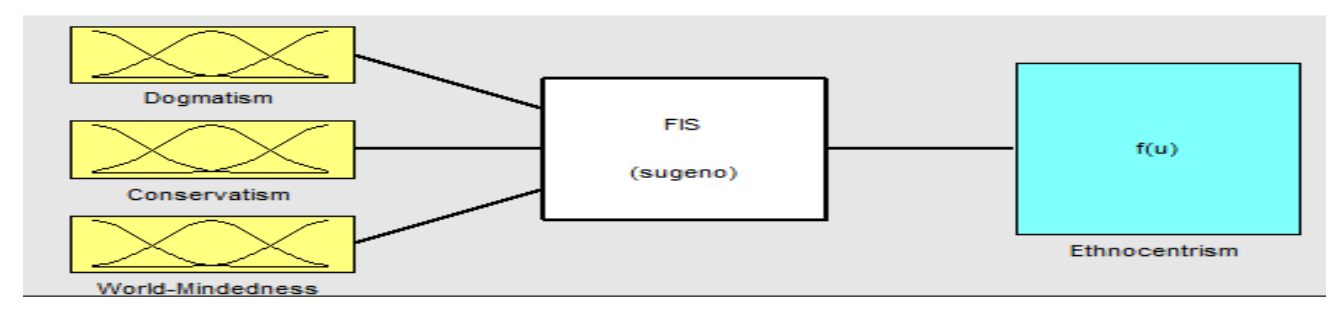

Fig1.Fuzzy System

After training the system with MATLAB $\AA$ ANFIS (number of epochs is 1000), the following membership functions are obtained (Figure 2): 


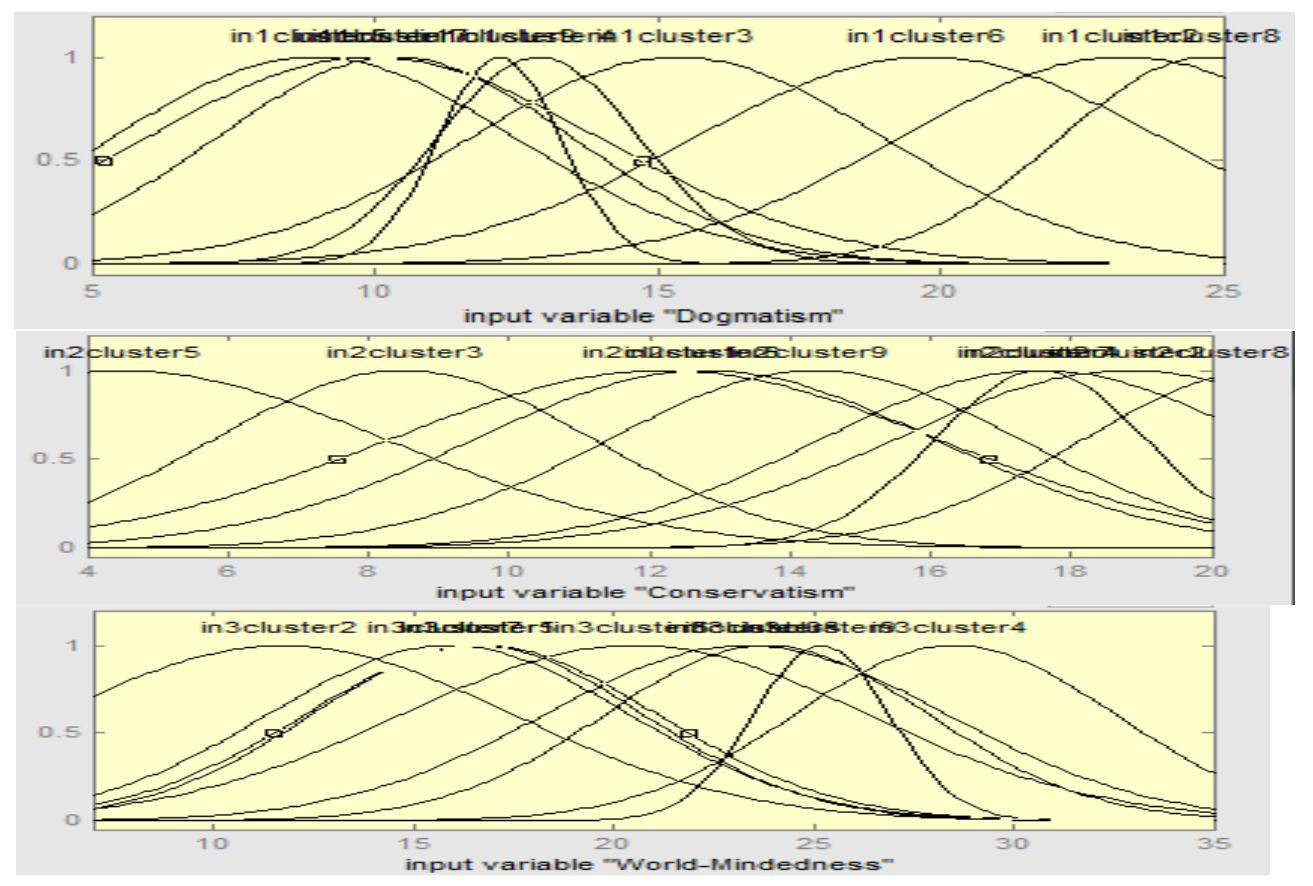

Fig2.Membership Functions

Table 1 contains the output membership functions parameters.

Table 1: Output Membership Functions Parameters

\begin{tabular}{|c|c|c|c|c|}
\hline $\begin{array}{c}\text { Membership } \\
\text { Function \# }\end{array}$ & $\mathrm{h}$ & $\mathrm{i}$ & $\mathrm{j}$ & $\mathrm{r}$ \\
\hline 1 & 6.098977 & 50.8763 & -3.82274 & -533.518 \\
\hline 2 & 4.621039 & 0.313815 & -0.26705 & -10.7106 \\
\hline 3 & -2.82831 & 7.467427 & -0.37717 & 58.0483 \\
\hline 4 & 3.826306 & -24.0989 & -9.62628 & 773.3794 \\
\hline 5 & 1.879656 & 38.55335 & 0.357392 & -75.8293 \\
\hline 6 & 11.36532 & -5.86963 & 0.296754 & -107.681 \\
\hline 7 & 15.44122 & 24.2285 & -5.54082 & -526.835 \\
\hline 8 & -32.4703 & -10.8125 & 1.249657 & 1059.462 \\
\hline 9 & -74.0144 & -42.5621 & -82.2798 & 3456.33 \\
\hline
\end{tabular}

Figures 3(a), 3(b) and 3(c) describe the nature of the relationships between sociopsychological variables; namely, dogmatism, conservatism and world-mindedness and consumer ethnocentrism individually. 


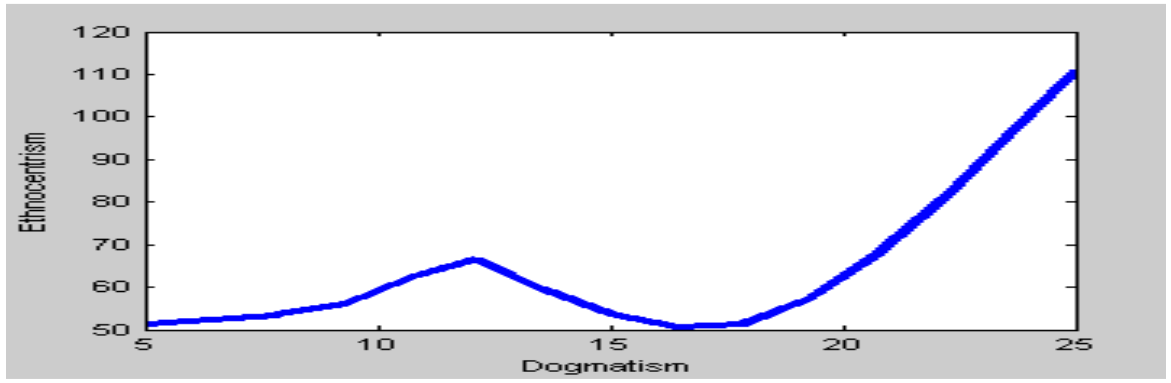

Fig3(a).Dogmatism and Consumer Ethnocentrism Relationship

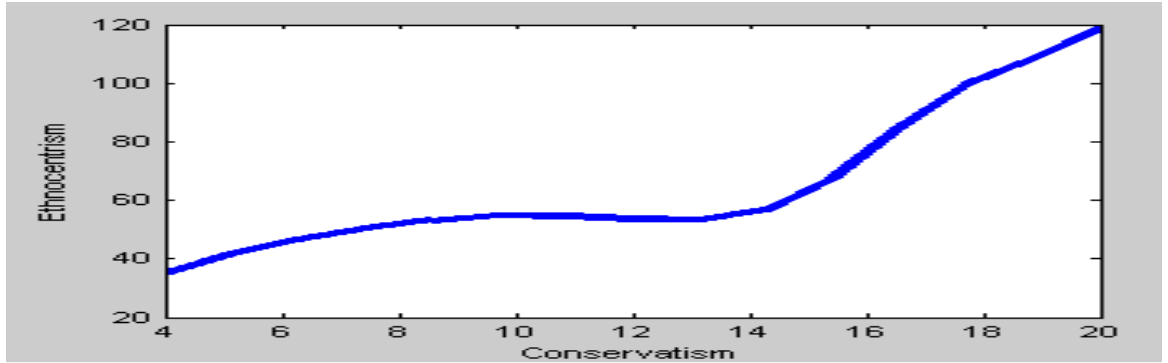

Fig3(b).Conservatism and Consumer Ethnocentrism Relationship

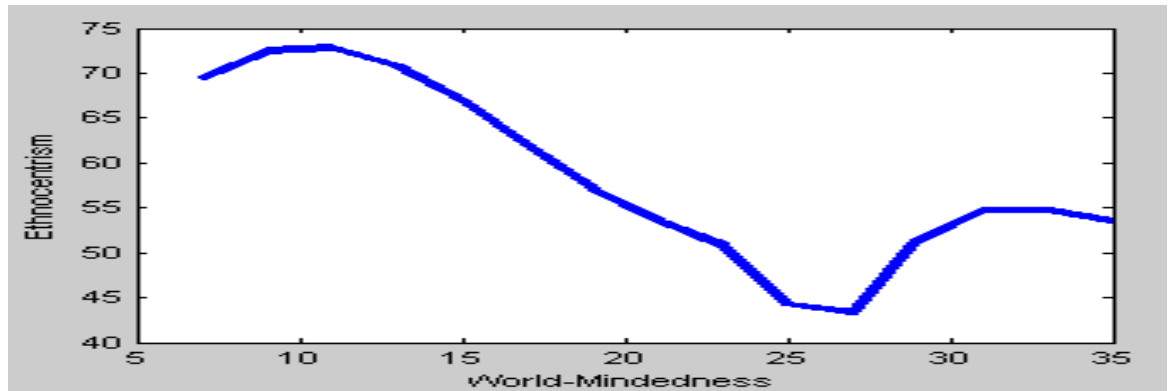

Fig3(c).World-mindedness and Consumer Ethnocentrism Relationship

Figure 3(a) shows that there is a proportional relationship between consumer ethnocentrism and dogmatism which implies that people with high level of dogmatism will show high ethnocentric tendencies. Also, it is clear from Figure 3(b) that a proportional relationship is found between conservatism and ethnocentrism implying that conservative consumers have high ethnocentric tendencies towards their local products. On the other hand, Figure 3(c) shows an inverse relationship between world-mindedness and consumer ethnocentrism. Consumers who have emotional support for the problems of humanity express low consumer ethnocentrism towards purchasing their domestic products. Regression results have confirmed the abovementioned results (Table 2). The results show that dogmatism and conservatism have significant positive influence on consumer ethnocentrism. However, it is clear that world-mindedness has negative significant influence on consumer ethnocentrism. Conservatism has the strongest influence on consumer ethnocentrism. 
Table 2: Regression on Consumer Ethnocentrism

\begin{tabular}{|c|c|c|c|c|}
\hline & \multicolumn{2}{|c|}{$\begin{array}{l}\text { Unstandardised } \\
\text { Coefficients }\end{array}$} & \multirow{2}{*}{$\begin{array}{c}\text { Standardised } \\
\text { Coefficients } \\
\text { Beta }\end{array}$} & \multirow[t]{2}{*}{ Sig. } \\
\hline & B & $\begin{array}{l}\text { Std. } \\
\text { Error }\end{array}$ & & \\
\hline (Constant) & 54.00 & 4.67 & & 0.000 \\
\hline World-mindedness & $\begin{array}{c}- \\
0.862\end{array}$ & 0.149 & -0.280 & 0.000 \\
\hline Dogmatism & 0.602 & 0.182 & 0.175 & 0.001 \\
\hline Conservatism & 1.883 & 0.242 & 0.421 & 0.000 \\
\hline
\end{tabular}

Dependent Variable: CETSCAL

Figures 4(a), 4(b) and 4(c) represent three dimensional graphs that describe the effect of two inputs at a time on consumer ethnocentrism.

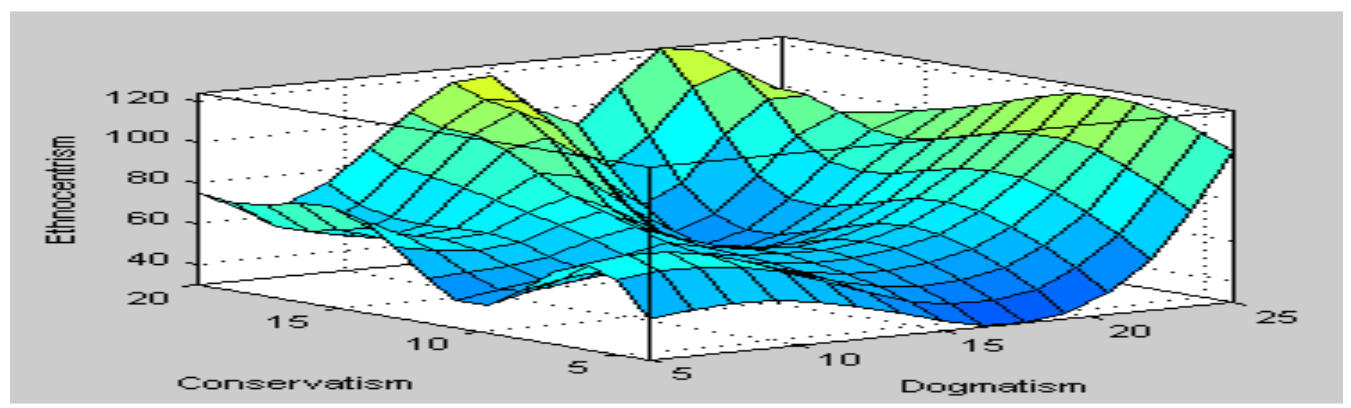

Fig4(a).Dimensional Graph (Dogmatism, Conservatism and Consumer Ethnocentrism)

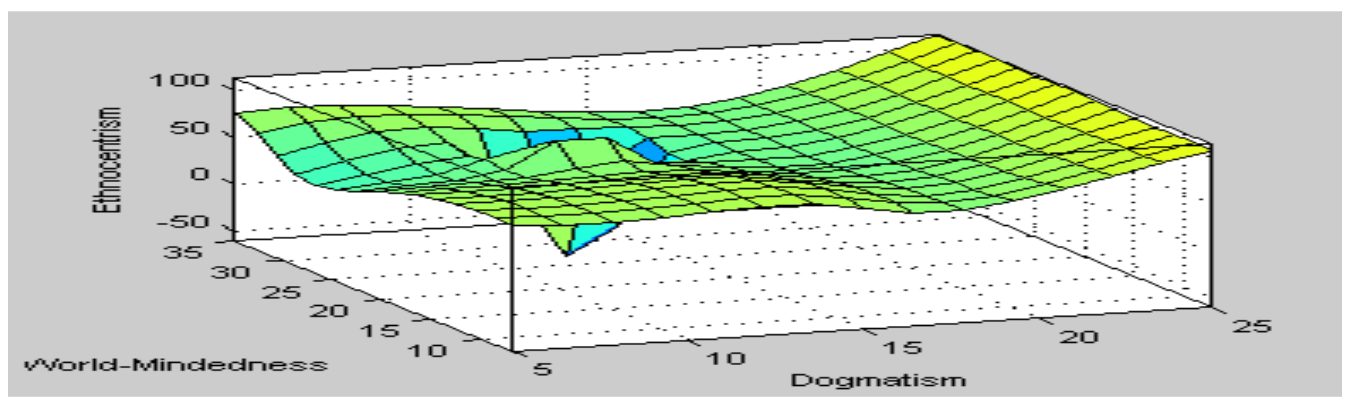

Fig4(b).Dimensional Graph (Dogmatism, World-mindedness and Consumer Ethnocentrism) 


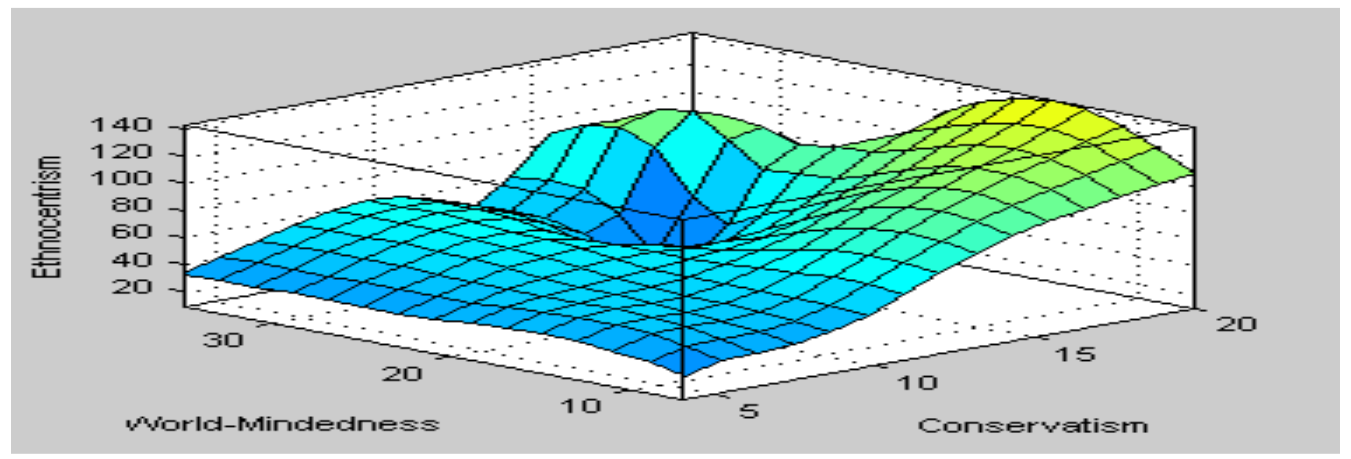

\section{Fig4(c).Dimensional Graph (Conservatism, World-mindedness and Consumer Ethnocentrism)}

It can be concluded from Figures 4(a), 4(b) and 4(c) that consumers with high level of dogmatism and high level conservatism will express high ethnocentric tendencies. However, for consumers with high dogmatism level, high ethnocentric tendencies are expected regardless of the level of world-mindedness they show. Moreover, it is expected for highly conservative consumers to show high ethnocentrism regardless of their world- mindedness level. One of the best benefits of this Sugeno type fuzzy model is that one can predict the degree of ethnocentrism of a certain consumer by simply entering two of the examined three inputs in this study dogmatism, conservatism and worldmindedness. Moreover, one can predict using the Sugeno model for two different costumers who has higher ethnocentric tendencies simply by having only three inputs for those two consumers.
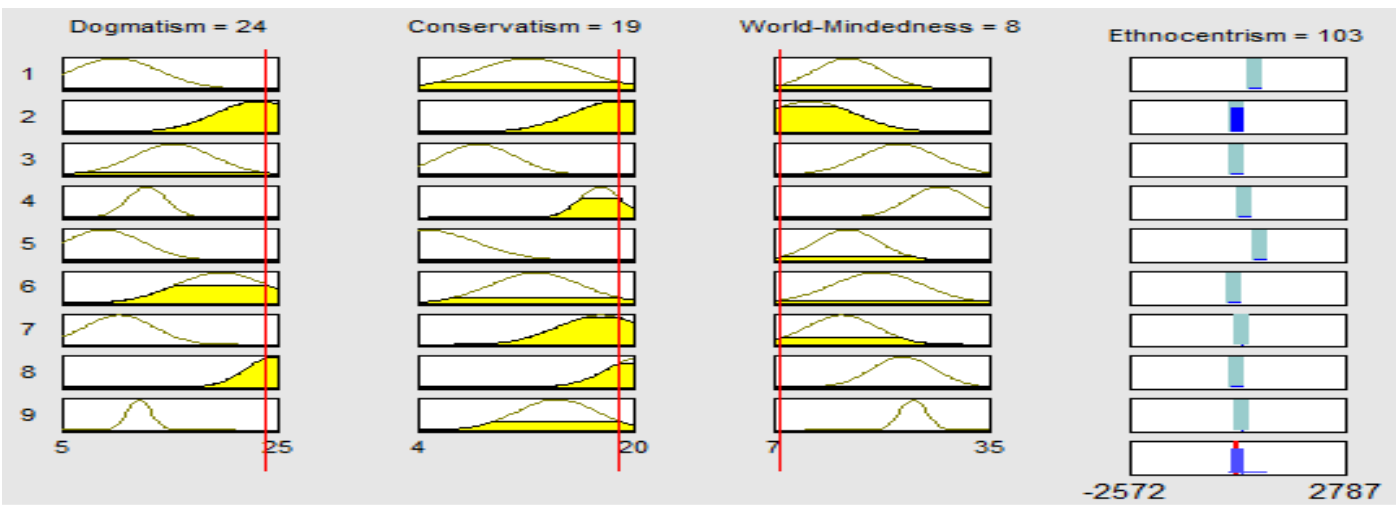

Fig5. Inputs and Output for a Particular Consumer (Example 1)

As an example of the aforementioned case, see the following situation. Figure 5illustrates the inputs and output for a particular consumer. Based on the consumer dogmatism, conservatism and worldmindedness levels and using the Sugeno type fuzzy model, the consumer should show high ethnocentric feelings and score roughly 103 out of 119 on a 17 -item CETSCALE. The real CETSCALE value for this consumer based on Sugeno type fuzzy model is 113 which is very close to 103.Figure 6is related to another consumer with different inputs of sociopsychological variables (dogmatism, conservatism and world-mindedness). Employing Sugeno model, one can predict 
based on the consumer's level of dogmatism, conservatism and world-mindedness that the consumer will express low consumer ethnocentrism and will score around 47.6 out of 119 on a 17-item CETSCALE. The actual CETSCALE score is roughly identical to what the model predicts, the consumer has scored 44 on a 17-item CETSCALE.
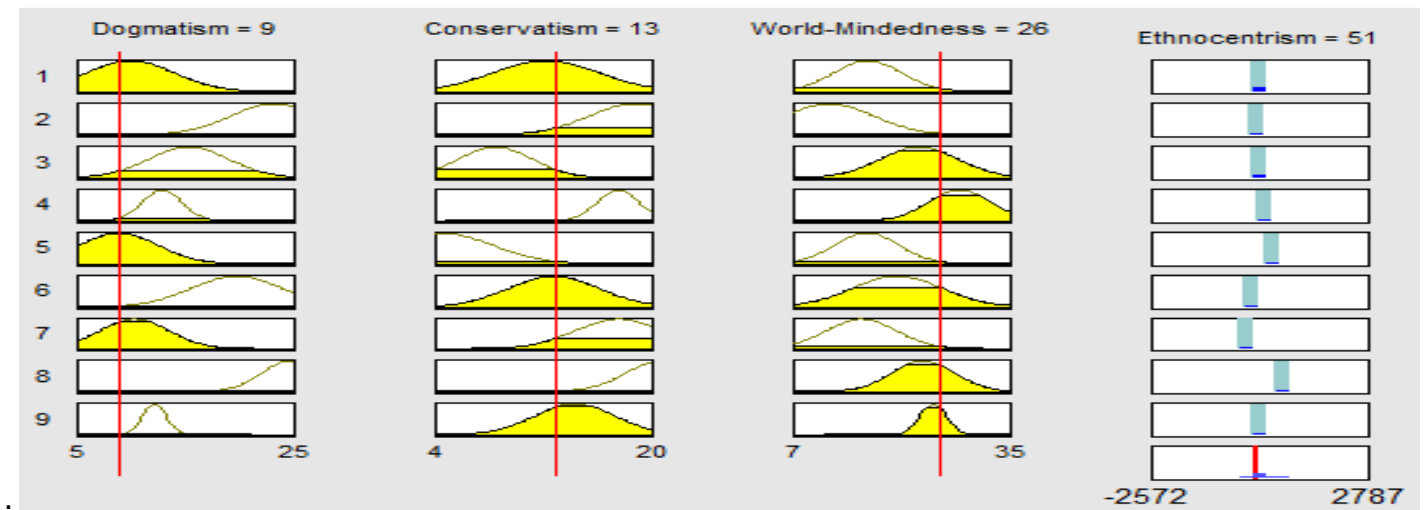

Fig6.Inputs and Output for a Particular Consumer (Example 2)

\section{Conclusions}

Global marketers should increase their understanding of how consumers in different countries perceive foreign products. The concept of consumer ethnocentrism provides marketers with better understanding of why consumers prefer to buy domestic or foreign products. However, companies that want to go globally should not undervalue consumer ethnocentric tendencies. Socio- psychological variables could help marketers to know more regarding the sources of consumer ethnocentrism phenomenon. Fuzzy model has approved to be beneficial and accurate in predicting the consumers' ethnocentric tendencies level based on their sociopsychological variables. The results of this study are promising and can help international marketing researchers to predict consumers' ethnocentrism based on their socio- psychological variables. It can be concluded that the impact of sociopsychological variables on consumer ethnocentrismmay be country or culture specific. Dogmatism and conservatism were found to have a significant positive influence on consumer ethnocentrism; however, world-mindedness has a negative significant influence. Conservatism has the strongest influence on consumer ethnocentrism.

\section{References}

Al Ganideh, S. F. (2010). "Consumer Ethnocentrism in the Jordanian Market: the Impact of Socio-Psychological Variables on Consumer Ethnocentric Tendencies," Journal of Business \& Retail Management Research, 5(1), 11-20.

Al Ganideh, S. F., Elrefae, G. A. \& Aljanaideh, M. (2012). "Can Fuzzy Logic Predict Consumer Ethnocentric Tendencies? an Empirical Analysis in Jordan," Journal of Physical Science and Application, 1 (2012), 100-106.

Al Ganideh, S. F., Jackson, H. \& Marr, N. (2007). 'An Investigation into Ethnocentrism among Young Jordanians,' World Journal of Retail Business Management, 2(1), 40-51.

Balabanis, G., Diamantopoulos, A., Mueller, R. D. \& Melewar, T. C. (2001). "The Impact of Nationalism, Patriotism and Internationalism on Consumer Ethnocentric Tendencies," 
Journal of International Business Studies, 32 (1), Pp.157-175.

Blitz, M. (2010). "What Conservatism Retains," Policy Review, 161, 61-71.

Bruning, E. R. (1997). "Country of Origin, National Loyalty and Product Choice: the Case of International Air Travel," International Marketing Review, 14 (1), 5974.

Bruning, E. R., Kovacic, M. L. \& Oberdick, L. E. (1985). "Segmentation Analysis of Domestic Airline Passengers Markets," Journal of the Academy of Marketing Science, 13(1-2), 1731.

http://dx.doi.org/10.1007/BF02729703

Caruana, A. \& Magri, E. (1996). "The Effects of Dogmatism and Social Class Variables on Consumer Ethnocentrism in Malta," Marketing Inelegance and Planning, 14 (4), 39-44.

Chéron, E. \& Hayashi, H. (2001). "The Effect of Respondents' Nationality and Familiarity with a Product Category on The Importance of Product Attributes in Consumer Choice: Globalization and the Evaluation of Domestic and Foreign Products," Japanese Psychological Research, 43(4), 183-194.

Chung, J.-E., Pysarchik, D. T. \& Hwang, S.-J. (2009). "Effects of Country-of-Manufacture and Brand Image on Korean Consumers' Purchase Intention," Journal of Global Marketing, 22, 21-41.

Crowson, H. M. (2009). "Does the DOG Scale Measure Dogmatism? Another Look at Construct Validity," the Journal of Social Psychology,149(3), 365-383.

De Ruyterk, K., Birgelen, M. V. \& Wetzels, M. (1998). "Consumer Ehnocentrism in International Services Marketing," International Business Review, 7, 185-202.

Enache, I. C. (2010). "Marketing a Web-Site Using a Fuzzy Logic Approach," Proceedings of the 10 International Conference on Risk Management, Assessment and Mitigation,2022 April 2010, Bucharest, Romania, 335-339.

Hair, J. F., Anderson, R. E., Tatham, R. L. \& Black, W. C. (1998). Multivariate Data Analysis, Prentice-Hall, Upper Saddle River, New Jersey.

Huddleston, P., Good, L. K. \& Stoel, L. (2001). “Consumer Ethnocentrism, Product Necessity and Polish Consumers' Perceptions of Quality," International Journal of Retail and Distribution Management, 29 (5), 236-246.

Javalgi, R. G., Khare, V. P., Gross, A. C. \& Scherer, R. F. (2005). "An Application of the Consumer Ethnocentrism Model to French Consumers," International Business Review, 14, 325-344.

Josiassen, A. (2012). "Consumer Disidentification and its Effects on Domestic Product Purchases: an Empirical Investigation in the Netherlands," Journal of Marketing, 75, $124-140$.

Kim, S. \& Pysarchik, D. T. (2000). "Predicting Purchase Intentions for Uni-National and BiNational Products," International Journal of Retail and Distribution Management,28 (6), 280-291.

Klein, J. G., Ettenson, R. \& Morris, M. D. (1998). "The Animosity Model of Foreign Product Purchase: an Empirical Test in the People's Republic of China," Journal of Marketing, 62 (January), 89-100.

Lee, W.-N., Hong, J.-Y. \& Lee, S.-J. (2003). "Communicating with American Consumers in the Post 9/11 Climate: an Empirical Investigation of Consumer Ethnocentrism in the United States," International Journal of Advertising,22, 487-510.

Lim, J- S. \& Darley, W. K. (2009). "Evaluations of Foreign-Made Products in a Limited Choice Environment: a Replication and Extension of the Direct Mediation Model," the Marketing Management Journal, 19(1), 96112. 
Liu, C.-H. (2009). "The Development and Application of a Group Decision Model Using Fuzzy Logic: the Case of Consumer Attitudes Towards Risk," International Journal of Management,26 (2), 261-271.

Nijssen, E. J. \& Herk, H. V. (2009). “Conjoining International Marketing and Relationship Marketing: Exploring Consumers' CrossBorder Service Relationships," Journal of International Marketing, 17(1), 91-115.

Orth, U. R. \& Firbasova, Z. (2003). "The Role of Consumer Ethnocentrism in Food Product Evaluation," Agribusiness,19 (2), 137-153.

Pecher, A. \& Tregear, A. (2000). "Product Country Image Effects for Food Products: the Case of German Cheese in the UK," Journal of International Food and Agribusiness Marketing, 11(3), 1-15.

Phau, I. \& Chan, K.-W. (2003). “Targeting East Asian Markets: a Comparative Study on National Identity," Journal of Targeting, Measurement and Analysis for Marketing, 12 (2), 157-172.

Rawwas, M. Y. A. , Rajendar, K. N. \& Wuehrer, G. A. (1996). "The Influence of Worldmindedness and Nationalism on Consumer Evaluation of Domestic and Foreign Products," International Marketing Review, 13 (2), 20-38.

Ray J. J. (1983). "A Scale to Measure Conservatism of American Public Opinion," Psychology,119,293-294.

Sekaran, U. \& Bougie, R. (2010). Research Methods for Business: A Skill Building Approach, John Wiley and Sons, West Sussex.

Shankarmahesh, M. N. (2006). "Consumer Ethnocentrism: an Integrative Review of its Antecedents and Consequences," International Marketing Review , 23 (2), 146172.

Sharma, S., Shimp, T. A. \& Shin, J. (1995). "Consumer Ethnocentrism: a Test of
Antecedents and Moderators," Journal of Academy of Marketing Science , 23 (1), 26-37.

Shimp, T. A. (1984). "Consumer Ethnocentrism: the Concept and a Preliminary Empirical Test," Advances in Consumer Research, 11, 285-290.

Shimp, T. A. \& Sharma, S. (1987). “Consumer Ethnocentrism: Construction and Validation of the CETSCALE," Journal of Marketing Research, 24 (3), 280-289.

Strauss, D. A. (2012). "Originalism, Conservatism, and Judicial Restraint," Harvard Journal of Law \& Public Policy.34(1), 137-146.

Sugeno, M. \& Kang, G. T. (1987). "Structure Identification of Fuzzy Model," Fuzzy Sets and Systems, 28, 15-33.

Weng, Y., Yang, C.-H. \& Tu, F.-C. (2010). "Outward Foreign Direct Investment and Product Quality of Domestic Productions: an Empirical Investigation," Journal of Business Economics and Management, 11(3), 396-414.

Wiersema, M. F. \& Bowen, H. P. (2008). "Corporate Diversification: the Impact of Foreign Competition, Industry Globalization, and Product Diversification," Strategic Management Journal, 29, 115-132.

Witkowski, T. H. (1998). "Consumer Ethnocentrism in Two Emerging Markets: Determinants and Predictive Validity," Advances in Consumer Research, 25,258-263.

Yu, J. H. \& Albaum, G. (2002). "Sovereignty Change Influences on Consumer Ethnocentrism and Product Preferences: Hong Kong Revisited One Year Later," Journal of Business Research, 55(11), 891-899.

Zadeh, L. A. (1965). "Fuzzy Sets," Information and Control , 8, 338-353. 


\section{Appendix (Constructs and Items Used)}

\section{CETSCALE (Shimp and Sharma, 1987)}

Jordanian people should always buy Jordanian-made products instead of imports.

Only those products that are unavailable in Jordan should be imported.

Buy Jordanian-made products, keep Jordan working.

Jordanian products, first, last and foremost. Purchasing foreign-made products is unJordanian.

It is not right to purchase foreign products, because it puts Jordanians out of jobs.

A real Jordanian should always buy Jordanian-made products.

We should purchase products manufactured in Jordan instead of letting other countries get rich off us.

It is always best to purchase Jordanian products.

There should be very little trading or purchasing of goods from other countries unless out of necessity.

Jordan should not buy foreign products, because this hurts Jordanian business and causes unemployment.

Curbs should be put on all imports.

It may cost me in the long run but I prefer to support Jordanian products.

Foreigners should not be allowed to put their products on our markets.

Foreign products should be taxed heavily to reduce their entry into Jordan.
We should buy from foreign countries only those products that we cannot obtain within our own country.

Jordanian consumers who purchase products made in other countries are responsible for putting their fellow Jordanians out of work.

\section{Conservatism}

Jordanian tribes should continue to have a central role in Jordanians' life.

Jordanians should respect and follow tribal laws when it is needed.

I do not support the new Jordanian Government laws which increase punishment on Jordanians who do honor killing.

Women in Jordan should not be appointed in top country positions.

\section{World-mindedness (Rawwas and Rejendran, 1996)}

I find imported goods more desirable than domestically produced products.

All national governments should be abolished and replaced by one central government.

It would be better to be a citizen of the world than of any particular country.

My quality of life would improve if more imported goods were available.

Immigration should be controlled by an international organization rather than by each country independently.

Where a good is produced does not affect my decision to purchase that item. 
Jordan should permit foreigners to immigrate here even if it lowers our standard of living.

\section{Dogmatism (Bruninget al 1985)}

I am not very insistent in an argument.

I do everything in my power in order not to have to admit defeat.

People find it difficult to convince me that I am wrong on a point no matter how hard they try.

I would get into a long discussion rather than admit that I am wrong.

When someone opposes me on an issue, I usually find myself taking an even stronger stand than I did at first. 